\title{
Creating a climate for expanded trade in wood products ${ }^{1}$
}

\author{
by Linda Coady ${ }^{2}$
}

This paper discusses some of the environmental aspects of forest products trade. There is no doubt that environmental issues are becoming more closely aligned with trade issues in the Canadian forest products sector. Environmental issues and initiatives are beginning to be used - or certainly have the potential to be used - to restrict trade and distort competition.

We are already seeing concepts designed to promote or measure environmental sustainability used in marketing - including concepts like Best Available Technology (BAT), Life Cycle Analysis (LCA), Chain of Custody, ecolabelling, and the independent auditing and benchmarking of environmental performance. The drive for competitive advantage in the marketplace is moving beyond the traditional factors of quality, service and value - and embracing "softer" assets such as intellectual capital, reputation and trust, and environmental and social responsibility.

All of these factors are uniting to create a climate in which:

- negotiations by international bodies on multilateral agreements on forests and environmental issues are becoming more common

- legislative and regulatory initiatives by government on environmental issues are becoming more stringent and complex

- non-regulatory (or voluntary) initiatives by industry on environmental performance and management systems are becoming more common and global.

Systems for voluntary certification of corporate environmental management and performance are currently being very actively investigated, tested and debated - particularly in Europe. European initiatives on eco-auditing and labelling, as well as the establishment of "buyers groups" - such as the UK's Group of /95 for the Do-It-Yourself Home Centre trade — are beginning to influence thinking and events here in North America.

The current government focus on multilateral agreements on forests and environmental issues, and current industry focus on the development of private standards for environmental certification of management systems, are both being influenced by concern about the impact of the intermingling of trade and environmental issues. There is justifiable apprehension regarding the emergence of non-tariff barriers to trade in forest products under the guise of environmental protectionism if something isn't done to maintain a level playing field. Given the importance of forest products exports to Canada, our country probably has more at stake than most in trying to keep that playing field as level as possible.

Naturally, the irony is that no matter how well intentioned to the extent that these various initiatives are becoming requirements for market access, they are in themselves becoming restrictions to trade - leaving one to ponder whether the cure is indeed sometimes worse than the disease.

\footnotetext{
${ }^{1}$ Paper presented at the Semi-Annual Meeting of the Canadian Wood Council, 21 October 1996, Ottawa.

${ }^{2}$ Vice-President, Environmental Affairs, MacMillan Bloedel Ltd., Vancouver.

${ }^{3}$ The McKinsey Quarterly, 1995, No. 2, The Real Green Issue, p. 136.
}

Nevertheless, the reality is that new financial drivers with environmental parameters are emerging at a global level. These include risk avoidance in project financing and insurance, and increasing political interest in "green" taxes and credits and "full cost accounting" requirements.

In addition, the social investment movement in Europe and

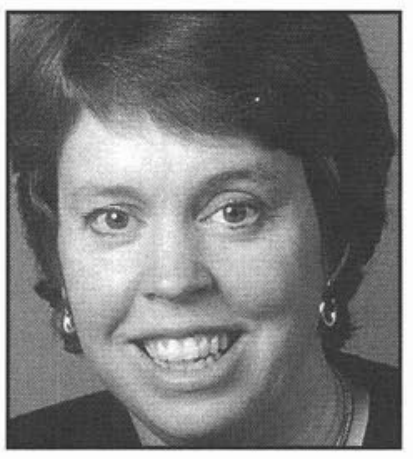
North America is growing as some investors and environmental groups turn to investor and consumer advocacy as a way of trying to reward certain types of behaviour and punish others. What it all means is that there is increasing pressure on corporations selling in international markets to fully disclose the environmental impacts of their production processes and activities, and find ways to demonstrate not only compliance and due diligence, but continuous improvement in environmental performance. We live in a time when, from an environmental perspective, meeting legal requirements alone may not be enough to maintain or increase marketshare.

This raises the possibility that in the 1990s it may not simply be enough for Canadian forest companies to make quality products that people need. They may also have to be made in a way in which people approve. Moreover, should any of us in industry think that enhanced environmental sensitivity and performance is an excuse for not being cost competitive - think again.

There is no evidence I am aware of that indicates buyers or consumers are prepared to pay a premium for forest products with seemingly more attractive environmental attributes. To the contrary, the UK Buyers Group of /95, for example, has clearly indicated that reconciling competing tensions between environmental and economic objectives is sometimes entirely the producers problem.

It is a serious problem because, while the general demand for companies to be able to demonstrate the environmental appropriateness of both forest practices and manufacturing processes is clear, the prescriptions for how to go about actually achieving this vary widely.

In fact, there is little agreement on precisely what kinds of practices make forest products and processes acceptable or unacceptable from an environmental point of view. So although there are lots of ideas, opinions and consultants on environmental sustainability in a forest products context, no one really knows how to measure what works and what doesn't.

A recent quote from a business management journal - The McKinsey Quarterly ${ }^{3}$ — sums up the current dilemma from a corporate perspective.

The time when corporate environmental strategy meant controlling costs by fending off regulation for as long as possible and then doing the bare minimum to comply is long 
gone. But now the pendulum has swung to the opposite extreme, with many business executives now simply espousing the notion, "Just do the right thing and the rest will follow.

But even in an ideal world where all green opportunities would be economically attractive, no company could do everything. And what do people mean by the 'right thing' in an environmental context anyway? That which science dictates? What regulators want? What social and environmental activists value? What the public desires? What consumers would like?

These are often poles apart, leading down completely different paths.

What are the implications for government and industry of the brave, new trade universe that is unfolding for Canadian forest products? The answer probably varies and I can only speak from an MB perspective. Our company has probably been more engaged in these issues than most during the past few years hence a warning that our views may be somewhat different from the norm.

Survival Tip \#1 for the new forest products trade universe comes from the "Hitchiker's Guide" to the old universe.

\section{It is: Don't Panic!}

Tip \#1 for Survival in the New Forest Products Trade Universe becomes particularly important when you hear Tip \#2 for Survival in the New Forest Products Trade Universe, which is that although some degree of coordination between government and industry on the environmental aspects of forest products trade issues is desirable, it is also OK- and probably quite inevitable - that government and industry are not always going to see eye-to-eye on all this stuff. In fact, even within government and industry it is $\mathrm{OK}$ - and probably quite inevitable that people aren't always going to see eye-to-eye on things. Indeed, it may even be possible that within the environmental movement, people don't always see eye-to-eye on environmental issues.

I think it would be fair to characterize government as currently trying to deal with convergence between trade and environmental issues through the use of legislation, regulation and multi-lateral agreements. Meanwhile, industry is trying to deal with them through the use of non-regulatory instruments, usually voluntary, that focus on industry standards of performance and development of new criteria for internal environmental management systems (EMS), including third-party audits and mechanisms for continuous improvement.

Meanwhile, environmental groups are hopping back and forth between these two tracks - throwing in consumer and investor advocacy on environmental issues as added incentives for both government and industry to move faster.

In theory, the activities of government and industry should complement each other, but in practice, views differ depending on the realities experienced by those involved. Obviously no single group - be it government, industry or environmental non-government organizations (ENGOs)- has the market cornered on the only game in town. So it is a big playing field, with lots of activity, and where individuals players choose to engage - or even if they choose to engage - depends on their own needs and constraints.
For example, for some forest companies, environmental certification is a pressing issue; for others, it simply is not. Because of our needs, we at MB are actively exploring certification for Sustainable Forest Management (SFM), and have been involved with the efforts of the Canadian Standards Association (CSA) to develop a national standard in this area.

However, our experience on the environmental front during the past few years has also lead us to conclude that limited environmental group involvement in the CSA process is a concern, and that we should try to come to an accommodation with environmental groups to clarify - if not agree upon - some common and objective indicators of exactly what constitutes environmentally sustainable forest practices. To this end, our Chief Forester, Bill Cafferata, is engaged in an effort to involve social and environmental groups participating in the Canadian Forest Stewardship Council (FSC) in a joint effort on these issues.

If I had to condense all that we at MB have learned from our experiences on the environmental front during the past few years, it would be to not be afraid of complexity or differentiation on these matters. In fact, sometimes differences and complexities can actually be quite helpful in the sense that they can reduce polarization by presenting people with more choices than just one position versus another.

Of course, the trouble with complexity is that it is complex. When you get a lot of different things happening at a lot of different levels all at once, it can be very difficult for people to figure out what is going on. The other problem with complexity is that it can sometimes lead to gridlock if people or systems are not equipped to handle it.

I would argue, however, that is is worth the struggle because it is only in having to suffer the risks associated with differentiation, and grapple with complexity, that the main protagonists in these debates - usually industry and environmental groups - are pushed hard enough that they are actually forced to grow beyond their original positions and capacities for coming to terms with the issues involved.

Again, going back to our experience with the mother of all forest-related environmental conflicts in Canada - Clayoquot Sound - it has only been since the environmental groups began to grapple with economic transition in a way that they hadn't before - and our company began to grapple with defining sustainable forestry within the context of conservation in a way in which we hadn't before - that the whole picture began to tilt a bit and the dynamic started changing. A book about biodiversity by an American ecologist named Daniel Botkin (called "Discordant Harmonies") puts forth the basic argument that discordant harmonies - or species constantly competing with other species in a process of neverending and not always very balanced change - lies at the basis of the biodiversity that accounts for the fundamental vitality and resilience of Nature. I'd like to think that perhaps the same concept can be helpful when trying to come to grips with the impact of environmental issues on forest products trade. Perhaps, despite the risks and complexities, it is indeed possible for industry, and others, to learn how to live - and maybe even thrive - amidst discordant harmonies on the trade front as it relates to environmental issues.

If you believe that the fundamental vitality and resilience of business stems from the quest for competitive advantage and the energy and commitment of individuals - a bit of "discordant harmony" on these issues might even by a very good thing. 